DOI: $10.19195 / 2084-5065.46 .4$

\title{
Niebezpieczeństwo wyrządzenia znacznej szkody majątkowej jako skutek przestępstwa bezszkodowej niegospodarności
}

\author{
AnNA PŁOŃSKA \\ Katedra Prawa o Wykroczeniach, Karnego Skarbowego i Gospodarczego \\ Wydział Prawa, Administracji i Ekonomii Uniwersytetu Wrocławskiego
}

O doniosłości przestępstwa niegospodarności jako narzędzia karnoprawnej ochrony obrotu gospodarczego świadczy fakt umieszczenia rozbudowanego art. 296 na początku rozdziału XXXVI kodeksu karnego. Aksjologicznym uzasadnieniem wprowadzenia karalności niegospodarności z art. $296 \S 1$ k.k. jest fakt naruszenia przez sprawcę nierozerwalnie połączonych z prowadzeniem działalności gospodarczej dóbr w postaci profesjonalizmu, uczciwości, rzetelności oraz staranności ${ }^{1}$. W powyższym przepisie jest bowiem zawartych siedem typów karalnej niegospodarności, wśród których ustawodawca w $\S$ la ujął bezszkodową niegospodarność, w $§ 2$ zaś — jej kwalifikowany typ ze względu na cel osiągnięcia korzyści majątkowej².

1 M. Ligęza-Turlakiewicz, G. Turlakiewicz, Granice kreatywnego zachowania menadżerów w kontekście art. 296 § la kodeksu karnego, „Państwo i Prawo” 2016, nr 5, s. 52-53.

2 R. Zawłocki, [w:] System Prawa Karnego, t. 9. Przestęstwa przeciwko mieniu i gospodarcze, red. R. Zawłocki, Warszawa 2011, s. 450 n.

Nowa Kodyfikacja Prawa Karnego 46, 2017

(C) for this edition by CNS 
Przestępstwo bezszkodowej niegospodarności zostało dodane do katalogu przestępstw przeciwko obrotowi gospodarczemu na mocy ustawy z dnia 9 czerwca 2011 r. o zmianie ustawy - Kodeks karny oraz niektórych innych ustaw ${ }^{3}$. Wprowadzenie nowego typu przestępstwa do art. $296 \S 1$ la k.k. było niejako konsekwencją uchylenia na mocy tej samej nowelizacji art. 585 k.s.h. I. Sepioło zwraca uwagę, iż do jednej z największych wad art. 585 k.s.h. należało użycie płynnego i niedookreślonego zwrotu „działania na szkodę spółki” w strukturze jego znamion strony przedmiotowej. Postulowane wówczas zmiany odnoszące się do dookreślenia powyższego sformułowania jako „narażenia spółki handlowej na bezpośrednie niebezpieczeństwo wyrządzenia jej znacznej szkody majątkowej" uzyskały poparcie Komisji Kodyfikacyjnej, co ostatecznie doprowadziło do uchylenia art. 585 k.s.h. i wprowadzenia jego zmodyfikowanej wersji do nowego typu czynu zabronionego z art. 296 § 1a k.k., co w konsekwencji poskutkowało zawężeniem kryminalizacji bezszkodowej niegospodarności ${ }^{4}$.

Wprowadzenie uprzywilejowanego typu przestępstwa nadużycia zaufania z art. 296 § 1a k.k. spotkało się w doktrynie z wyraźną krytyką ${ }^{5}$. Nie ulega wątpliwości, że przepis ten budzi w doktrynie wiele kontrowersji, wśród których najczęściej wymienia się brak podstaw do karnoprawnej ochrony przed niegospodarnością wyłącznie w obrocie gospodarczym, a także kryminalizację bezszkodowych zachowań, nieumyślnego popełnienia przestępstwa, czy wreszcie jego publicznoskargowy tryb ścigania 6 .

W pierwszej kolejności wyjaśnienia wymaga samo pojęcie niegospodarności, któremu nadawany jest prawno-ekonomiczny sens w postaci naruszenia swoich kompetencji przez sprawcę oraz w konsekwencji wyrządzenia przez niego znacznej szkody majątkowej, a w przypadku $\S$ 1a sprowadzenia bezpośredniego niebezpieczeństwa jej wyrządzenia.

3 Dz.U., Nr 133, poz. 767.

4 I. Sepioło, Przestępstwo niegospodarności z art. 296 k.k., Warszawa 2013, s. $137 \mathrm{n}$.

5 R. Zawłocki, Nowe przestępstwo niegospodarności bezszkodowej z art. 296 § 1 a Kodeksu karnego, „Monitor Prawniczy” 2011, nr 18, s. 965.

6 I. Zgoliński, [w:] Kodeks karny. Komentarz, red. V. Konarska-Wrzosek, Warszawa 2016, s. 1235.

Nowa Kodyfikacja Prawa Karnego 46, 2017

(C) for this edition by CNS 
Słownik języka polskiego definiuje przymiotnik „niegospodarny” jako „nieumiejący dobrze gospodarować, zarządzać czymś”7. W związku z powyższym niegospodarnością można nazwać zachowanie (działanie lub zaniechanie) wynikające $\mathrm{z}$ braku umiejętności gospodarowania czy zarządzania czymś. Niegospodarnością bezszkodową w kontekście omawianego przepisu będzie zatem nieumiejętne gospodarowanie, będące wynikiem nadużycia udzielonych sprawcy uprawnień lub niedopełnienia ciążącego na nim, na podstawie przepisu ustawy, decyzji właściwego organu lub umowy, obowiązku związanego z zajmowaniem się sprawami majątkowymi lub działalnością gospodarczą reprezentowanej osoby fizycznej, osoby prawnej lub jednostki niemającej osobowości prawnej, które powoduje w konsekwencji sprowadzenie bezpośredniego niebezpieczeństwa wyrządzenia jej znacznej szkody majątkowej. Na marginesie dodać należy, że w kontekście samego określenia przestępstwa z art. 296 k.k. jako niegospodarności w doktrynie nie ma jednolitości. Niektórzy autorzy twierdzą, że niegospodarność była zjawiskiem typowym dla gospodarki uspołecznionej, w której system gospodarczy opierał się na przedsiębiorstwach państwowych i spółdzielczych. W nowych zaś warunkach gospodarczych zjawisko niegospodarności winno być skutecznie eliminowane z życia gospodarczego ${ }^{8}$. $Z$ tego m.in. powodu w doktrynie oraz w orzecznictwie przestępstwo z art. 296 k.k. bardzo często określane jest jako nadużycie zaufania, a sporadycznie również jako wyrządzenie szkody w obrocie gospodarczym.

Nie ulega wątpliwości, że znamiona czynu zabronionego ujęte w art. 296 k.k. odnoszą się ściśle do niegospodarnego zachowania w obrocie gospodarczym, a o jej karalnym wystąpieniu decyduje treść indywidualnych okoliczności ${ }^{9}$. Należy także dodać, że ze względu na specyfikę obrotu gospodarczego praktyczne stosowanie art. 296 k.k. winno opierać się na analizie znamion tego czynu zabronionego z jednoczesnym uwzględnie-

7 Stownik języka polskiego PWN, red. W. Doroszewski, Warszawa 1996-1997.

8 R. Zakrzewski, W. Jaroch, Przestępstwo nadużycia zaufania a zachowania niegospodarne, „Monitor Prawniczy” 1995, nr 8, s. 228.

9 R. Zawłocki, [w:] Kodeks Karny. Część szczególna. Komentarz, red. R. Królikowski, R. Zawłocki, t. 2, Warszawa 2013, s. 717-718. 
niem okoliczności związanych z dozwolonym ryzykiem gospodarczym osadzonym w istniejących w czasie popełnienia czynu realiach ${ }^{10}$.

Rodzajowym przedmiotem ochrony karnoprawnej wszystkich przepisów ujętych w rozdziale XXXVI k.k. jest prawidłowość i rzetelność obrotu gospodarczego, który utożsamiać należy z całokształtem stosunków gospodarczych opartych na działalności kumulatywnie cechującej się legalnym, zawodowym, zarobkowym oraz zorganizowanym i ciągłym sposobem jej wykonywania, a tym samym wpisującej się w legalną definicję działalności gospodarczej ujętą w art. 2 ustawy z dnia 2 lipca 2004 r. o swobodzie działalności gospodarczej ${ }^{11}$. Zgodnie bowiem z powyższym przepisem pod pojęciem działalności gospodarczej należy rozumieć zarobkową działalność wytwórczą, budowlaną, handlową, usługową oraz poszukiwanie, rozpoznawanie i wydobywanie kopalin ze złóż, jak też działalność zawodową, wykonywaną w zorganizowany i ciągły sposób. Indywidualnym zaś przedmiotem ochrony karnoprawnej w przypadku zarówno art. $296 \S 1$ k.k., jak i art. 296 § 1a k.k. są interesy majątkowe lub gospodarcze reprezentowanej przez sprawcę, na podstawie przepisu ustawy, decyzji właściwego organu lub odpowiedniej umowy, osoby fizycznej, prawnej albo jednostki organizacyjnej nieposiadającej osobowości prawnej. Niestety konkretyzacja indywidualnego przedmiotu ochrony w przypadku analizowanego przestępstwa nie jest prosta, a zdania doktryny i judykatury są podzielone między stanowiskiem, iż art. 296 k.k. chroni interesy jedynie przedsiębiorców, a stanowiskiem, iż przepis ten chroni interesy każdej osoby, niezależnie czy zajmuje się ona prowadzeniem działalności gospodarczej czy też nie ${ }^{12}$. Pomimo istnienia odmiennych stanowisk w tym zakresie, za trafne należy uznać wskazanie indywidualnego przedmiotu ochrony wszystkich odmian przestępstwa niegospodarności jako „prawidłowych relacji między osobą upoważnioną do zajmowania się sprawami majątkowymi

10 I. Zgoliński, [w:] Kodeks karny. Komentarz, red. V. Konarska-Wrzosek..., s. 1234.

11 T.j. Dz.U. z 2015 r., poz. 584 ze zm.; A. Płońska, Prawidłowy obrót gospodarczy jako przedmiot ochrony prawnokarnej na podstawie art. 299 \& 1 kodeksu karnego, „Państwo i Prawo” 2015, nr 10, s. 72.

12 A. Zientara, Przestępstwo nadużycia zaufania z art. 296 kodeksu karnego, Warszawa 2010, s. 276. 
i działalnością gospodarczą a mandantem, oraz właściwe wykonywanie powinności przez upoważnionego, mając również na względzie interesy majątkowe przedsiębiorcy" ${ }^{\prime 3}$.

Znamię skutku jest w zasadzie jedyną cechą odróżniającą typ przestępstwa z art. 296 § 1a k.k. od przestępstwa z art. 296 § 1 k.k. Kwestia powiązania karalnego zachowania ze skutkiem stanowiącym znamię omawianego czynu zabronionego jest o tyle problematyczna, że w przypadku zajmowania się sprawami majątkowymi lub działalnością gospodarczą mandanta na fakt powstania znacznej szkody, czy też sprowadzenia bezpośredniego niebezpieczeństwa jej wyrządzenia, może oddziaływać bardzo wiele czynników o różnorodnym charakterze. W związku z powyższym, w konkretnych stanach faktycznych, teoria adekwatności, nawiązująca do typowych następstw przyczynowych, wydaje się być optymalną podstawą ustalenia związku przyczynowego ${ }^{14}$. W sprawie powiązania powstania szkody majątkowej z umocowaniem do zajmowania się sprawami majątkowymi danego podmiotu SN wyraźnie wskazał, iż skutek zachowania sprawcy w postaci powstania szkody majątkowej może być powiązany jedynie z zachowaniem decyzyjnym, łączącym się z dużym prawdopodobieństwem wystąpienia niekorzystnych zmian w sferze praw majątkowych danego podmiotu ${ }^{15}$.

W prawie karnym brak jest legalnej definicji szkody majątkowej, w związku z powyższym należy ją rozpatrywać w ujęciu cywilistycznym. W literaturze przedmiotu szkoda majątkowa ujmowana jest jako „różnica pomiędzy obecnym stanem majątkowym a stanem hipotetycznym, który by istniał, gdyby nie nastąpiło dane zdarzenie ją powodujące" 16 , $\mathrm{i}$ jest ona definiowana zarówno jako damnum emergens — rozumiane jako zmniejszenie się aktywów majątku w wyniku ubytku, utraty lub zniszczenia jego poszczególnych składników albo w wyniku zwiększenia się pasywów, jak i lucrum cessans - rozumiane jako udaremnienie powiększenia się

13 J. Giezek, [w:] Kodeks Karny. Część szczególna. Komentarz, red. J. Giezek, Warszawa 2014, s. 1155.

14 M. Bojarski, [w:] Kodeks karny. Komentarz, red. M. Filar, Warszawa 2014, s. 1486.

15 Wyrok SN z 30 października 2013 r., II KK 81/13, OSNKW 2014, nr 3, poz. 25.

16 A. Muszyńska, Naprawienie szkody wyrzadzonej przestęstwem, Warszawa 2010, s. 73. 
owego majątku ${ }^{17}$. Dodać należy, że trudności, jakie mogą pojawić się w trakcie ustalania faktu powstania szkody lub jej wysokości, szczególnie w zakresie lucrum cessans, nie mogą prowadzić do pogwałcenia zasady określoności czynu przypisanego jako przestępstwo ${ }^{18}$.

W kontekście odpowiedzialności karnej za przestępstwo bezszkodowej niegospodarności, skutkujące sprowadzeniem bezpośredniego niebezpieczeństwa wyrządzenia znacznej szkody majątkowej, nie sposób nie wyobrazić sobie sytuacji, w której wprawdzie zachowanie sprawcy spowoduje skutek opisany w art. 296 § la k.k., ale też dojdzie równocześnie do wystąpienia nieznacznej szkody majątkowej. Aktualnie obowiązujący kształt przepisów nie przewiduje ukarania sprawcy za taką „podwójną szkodę"19.

R. Zawłocki szkodę majątkową, o której mowa w art. 296 k.k., wyraźnie utożsamia ze stratą finansową, stanowiącą notabene naturalny i nieodłączny element ekonomicznej aktywności, pozostawiając poza zakresem kryminalizacji tego przepisu efekt w postaci nieudanego przedsięwzięcia gospodarczego, jeżeli pozostawałoby ono w granicach uprawnień i obowiązków menedżera ${ }^{20}$. Samo pojęcie szkody majątkowej pojmowane jest zarówno w kontekście rzeczywistej straty (damnum emergens), jak i utraconego zysku (lucrum cessans). Przy czym SN wyraźnie wskazał, że „bez względu na opcję co do rozumienia pojęcia szkody majątkowej, na gruncie art. 296 k.k., warunkiem odpowiedzialności karnej za przestępstwo nadużycia zaufania w obrocie gospodarczym jest powstanie w wyniku działania sprawcy rzeczywistej szkody w majątku mandanta" ${ }^{21}$. Zatem szkoda ta ma dotyczyć wyłącznie strat lub braku przysporzeń po stronie osoby fizycznej, prawnej albo jednostki organizacyjnej niemającej osobowości prawnej, którą zarządzał sprawca ${ }^{22}$. O ile w przypadku przestępstwa nadużycia zaufania z art. $296 \S 1$ k.k. karalnym skutkiem jest wyrządzenie osobie fizycznej, osobie prawnej lub jednostce organizacyj-

17 Uchwała SN z 21 czerwca 1995 r., I KZP 22/95, OSNKW 1995, nr 9-10, poz. 58.

18 M. Bojarski, [w:] Kodeks karny. Komentarz, red. M. Filar..., s. 1485.

19 M. Ligęza-Turlakiewicz, G. Turlakiewicz, op. cit., s. 63.

20 R. Zawłocki, [w:] System Prawa Karnego..., s. 451.

21 Wyrok SN z 7 listopada 2005 r., V KK 108/05, OSNwSK 2005, nr 1, poz. 2000, KZS 2006, nr 12, poz. 13.

22 J. Potulski, [w:] Kodeks karny. Komentarz, red. R.A. Stefański, Warszawa 2015, s. 1718.

Nowa Kodyfikacja Prawa Karnego 46, 2017

(C) for this edition by CNS 
nej niemającej osobowości prawnej znacznej szkody majątkowej przez sprawcę obowiązanego przepisem ustawy, decyzją właściwego organu lub umową do zajmowania się jej sprawami majątkowymi lub działalnością gospodarczą, o tyle w przypadku przestępstwa bezszkodowego nadużycia zaufania określonego $\mathrm{w} \S$ 1a powyższego artykułu karalnym skutkiem jest samo sprowadzenie niebezpieczeństwa wyrządzenia takiej szkody. W przypadku przestępstwa bezszkodowej niegospodarności zamiarem sprawcy musi być objęte nie faktyczne wyrządzenie znacznej szkody majątkowej, lecz sprowadzenie bezpośredniego niebezpieczeństwa jej wyrządzenia. Zatem warunkiem karalności w tym przypadku jest zamierzone naruszenie przez sprawcę jego powinności gospodarczych, które jednocześnie stanowi bezpośrednie zmierzanie do wyrządzenia znacznej szkody majątkowej ${ }^{23}$. Konstrukcja określenia skutku jako sprowadzenia bezpośredniego niebezpieczeństwa z art. 296 § 1a k.k. nie jest wyjątkiem w regulacjach kodeksu karnego. Jak zauważa J. Giezek, realizacja tego elementu znamion uzależniona jest od wykazania, że zachowanie sprawcy kauzalnie i normatywnie jest powiązane z odpowiednio wysokim prawdopodobieństwem wystąpienia określonego rezultatu ${ }^{24}$.

Skutek składający się na znamię strony przedmiotowej przestępstwa bezszkodowej niegospodarności ujętej w art. 296 § 1a k.k. rozumiany jest jako sytuacja zagrożenia dla chronionego dobra prawnego w postaci interesów majątkowych mandanta, charakteryzująca się odpowiednio wysokim prawdopodobieństwem jego naruszenia, a wystąpienie znacznej szkody majątkowej, w okolicznościach braku konieczności jakiejkolwiek ingerencji ze strony sprawcy czy innego podmiotu, staje się realne, konkretne, wysoce prawdopodobne i wręcz graniczące z pewnością ${ }^{25}$. Według M. Gałązki bezpośrednie niebezpieczeństwo wyrządzenia znacznej szkody majątkowej cechuje się tym, iż w każdej chwili może się ono przekształcić w szkodę, której sprawca mógłby uniknąć poprzez należyte wykonanie swoich uprawnień i obowiązków ${ }^{26}$. SN zaś samo bezpośrednie

23 R. Zawłocki, [w:] System Prawa Karnego..., s. 483.

24 J. Giezek, [w:] Kodeks karny. Cześć szczególna. Komentarz, red. J. Giezek..., s. 1169.

25 Ibidem, s. 1172.

26 M. Gałązka, [w:] Kodeks Karny. Komentarz, red. A. Grześkowiak, K. Wiak, Warszawa 2012, s. 1232.

Nowa Kodyfikacja Prawa Karnego 46, 2017

(C) for this edition by CNS 
niebezpieczeństwo definiuje jako „niebezpieczeństwo grożące wprost, bez konieczności włączenia się dalszego impulsu ze strony sprawcy, bądź dodatkowej przyczyny, co oznacza tak zaawansowaną sytuację, że można w zasadzie mówić o bliskim skutku" 27 .

Karalny skutek czynu zabronionego w postaci sprowadzenia bezpośredniego niebezpieczeństwa wyrządzenia znacznej szkody majątkowej musi wykazywać cechę zaistnienia bezpośredniego i rzeczywistego niebezpieczeństwa wyrządzenia owej szkody, a nie rzeczywistego jej wyrządzenia ${ }^{28}$. Będzie to zatem sprowadzać się do konkretnego i realnego zagrożenia wyrządzenia szkody majątkowej, czyli do sytuacji, w której zachowanie sprawcy wywoła pewne zdarzenie stanowiące niebezpieczeństwo dla majątku mocodawcy, a wystąpienie ubytku w jego majątku nie będzie wymagało żadnego działania sprawcy lub osób trzecich, gdyż może ono powstać samoczynnie. Innymi słowy, składający się na znamię strony przedmiotowej skutek w postaci sprowadzenia bezpośredniego niebezpieczeństwa wyrządzenia znacznej szkody majątkowej należy rozumieć jako sprowadzenie konkretnego niebezpieczeństwa grożącego wprost, utożsamianego z tak zaawansowaną sytuacją, że można mówić o bliskim powstaniu znacznej szkody majątkowej w majątku podmiotu gospodarczego 29 .

Samo zagrożenie w postaci bezpośredniego niebezpieczeństwa wyrządzenia znacznej szkody cechuje się wysokim prawdopodobieństwem naruszenia chronionego dobra prawnego w postaci interesów majątkowych mandanta ${ }^{30}$. Znamię skutku w tym przypadku realizuje się na wcześniejszym etapie zamachu na interesy majątkowe mocodawcy. Kryminalizacją objęte jest zatem narażenie na niebezpieczeństwo konkretne ${ }^{31}$.

Według R. Zawłockiego niebezpieczeństwo wyrządzenia znacznej szkody majątkowej jako karalny skutek nadużycia zaufania w obrocie

27 Postanowienie SN z 28 listopada 2003 r., IV KK 23/03, OSNwSK 2003, poz. 2567.

${ }^{28}$ R. Zawłocki, [w:] Kodeks Karny. Część szczególna. Komentarz, red. R. Królikowski, R. Zawłocki..., s. 718.

${ }^{29}$ I. Sepioło, op. cit., s. 141-142.

30 J. Giezek, [w:] Kodeks Karny. Część szczególna. Komentarz, red. J. Giezek..., s. 1172.

31 M. Gałązka, [w:] Kodeks Karny. Komentarz, red. A. Grześkowiak, K. Wiak..., s. 1232. 
gospodarczym definiowane jest jako, oceniane na podstawie obiektywnych kryteriów, wywołanie przez sprawcę zachowania wskazanego w tym przepisie realnego zagrożenia samoczynnego powstania przynajmniej znacznej różnicy pomiędzy rzeczywistą wartością mienia pokrzywdzonego w chwili czynu a jego hipotetyczną wartością, która powstałaby, gdyby zagrożenie to przekształciło się w stan rzeczywistego pomniejszenia wartości majątku. Ponadto autor ten odwołuje się do braku wyrządzenia przez sprawcę znacznej szkody majątkowej, braku szkody majątkowej o wartości do 200000 zł oraz braku usiłowania wyrządzenia znacznej szkody majątkowej jako trzech negatywnych elementów współwyznaczających omawiany skutek ${ }^{32}$.

Istotnym problemem w kontekście niegospodarności bezszkodowej jest określenie wartości potencjalnej szkody majątkowej w czasie popełnienia przez sprawcę czynu zabronionego, tj. nadużycia przez sprawcę udzielonych mu uprawnień lub niedopełnienia jego obowiązku. Powyższa konstrukcja konstatuje wiele wątpliwości, gdyż nie da się wykluczyć sytuacji, w której do realizacji szkody dojdzie dopiero po pewnym czasie, a w warunkach zmiennych wskaźników ekonomicznych jej precyzyjne oszacowanie w czasie wykonania czynności sprawczej nierzadko będzie niemożliwe. Ponadto realia gospodarcze sprawiają, że wskazanie wyraźnych granic między ryzykiem spowodowania szkody, o którym mowa w art. 296 § 1a k.k., a jego eskalacją na skutek różnorakich mechanizmów gry rynkowej staje się mocno utrudnione ${ }^{33}$.

Należy też wyraźnie zaznaczyć, że zakresem kryminalizacji art. 296 $\S 1$ la k.k. objęte jest wyłącznie sprowadzenie bezpośredniego niebezpieczeństwa wyrządzenia znacznej szkody majątkowej. Oznacza to zatem, że poza zakresem kryminalizacji znajduje się zarówno pośrednie niebezpieczeństwo wyrządzenia znacznej szkody majątkowej, bezpośrednie i pośrednie niebezpieczeństwo wyrządzenia szkody majątkowej, która nie jest znaczna, jak i bezpośrednie i pośrednie niebezpieczeństwo wyrządzenia szkody niemajątkowej. „Okrojenie” przez ustawodawcę zakresu karalnego skutku do majątkowego charakteru szkody nie wyklucza jednak powstania bezpośredniego niebezpieczeństwa jej sprowadzenia

32 R. Zawłocki, [w:] Kodeks Karny. Część szczególna. Komentarz, red. R. Królikowski, R. Zawłocki..., s. 718.

33 M. Ligęza-Turlakiewicz, G. Turlakiewicz, op. cit., s. 61.

Nowa Kodyfikacja Prawa Karnego 46, 2017

(C) for this edition by CNS 
w wyniku naruszenia dóbr niematerialnych, jak np. dobre imię firmy, które da się wyrazić w określonej kwocie pieniędzy. Szkoda majątkowa jest bowiem definiowana jako szkoda, która jest możliwa do wyrażenia w określonej kwocie pieniężnej. Sama szkoda majątkowa zaś nie może być rozpatrywana w odniesieniu do całokształtu stosunków majątkowo-gospodarczych pokrzywdzonego, a jedynie do ich zakresu wytyczonego przez czynności sprawcze ${ }^{34}$.

$\mathrm{Na}$ uwagę zasługuje również analiza znamienia sprowadzenia bezpośredniego niebezpieczeństwa na tle usiłowania wyrządzenia znacznej szkody majątkowej. O ile bowiem w przypadku usiłowania czynu z art. 296 § 1 k.k. zamiarem sprawcy objęte jest wyrządzenie znacznej szkody majątkowej, o tyle w przypadku art. 296 § la k.k. zamiarem objęty jest etap poprzedzający powstanie szkody, a więc bezpośrednie niebezpieczeństwo jej zaistnienia ${ }^{35}$.

Na marginesie podjętych rozważań zauważyć należy, że klauzula niekaralności określona w art. $296 \S 5$ k.k. nie odnosi się do przestępstwa bezszkodowego nadużycia zaufania z racji braku możliwości spełnienia jej przesłanki, jaką jest dobrowolne naprawienie w całości wyrządzonej szkody przed wszczęciem postępowania karnego ${ }^{36}$. Wynika to jasno z wykładni językowej art. $296 \S 5$ k.k. Klauzula niekaralności została zatem przewidziana dla sprawców przestępstw nadużycia zaufania o poważniejszych skutkach. Zdaniem M. Gałązki powyższa ocena pozostaje niezmienna w przypadku przyjęcia na gruncie wykładni celowościowej, że art. 296 § k.k. może być zastosowany wobec sprawcy czynu z art. 296 $\S 1$ la k.k., powodującego szkodę majątkową, która nie jest znaczna ${ }^{37}$. Podobnie jest w przypadku usiłowania przestępstw z $§ 1-4$, jednakże wyłącznie w przypadku wyrządzenia przez sprawcę tylko części karalnej

34 R. Zawłocki, [w:] Kodeks Karny. Czesść szczególna. Komentarz, red. R. Królikowski, R. Zawłocki..., s. 713.

35 E. Hryniewicz, Karalne działanie na szkodę spółki, „Prokuratura i Prawo” 2012, nr 10, s. 78-79.

36 R. Zawłocki, [w:] Kodeks Karny. Część szczególna. Komentarz, red. R. Królikowski, R. Zawłocki..., s. 722.

37 M. Gałązka, [w:] Kodeks Karny. Komentarz, red. A. Grześkowiak, K. Wiak, Warszawa 2017, nlb. 16.

Nowa Kodyfikacja Prawa Karnego 46, 2017

(C) for this edition by CNS 
szkody, przy usiłowaniu wyrządzenia znacznej szkody majątkowej ${ }^{38}$. Nie jest bowiem możliwe karalne usiłowanie przestępstwa konkretnego narażenia na niebezpieczeństwo, gdyż samo przedsięwzięcie zachowania zmierzającego do sprowadzenia bezpośredniego niebezpieczeństwa wyrządzenia znacznej szkody majątkowej stanowi ze swej natury takie właśnie zagrożenie. Możliwość ukarania sprawcy za usiłowanie popełnienia bezszkodowej niegospodarności należy jednoznacznie odrzucić ${ }^{39}$.

Podsumowując podjęte rozważania, zgodzić się należy z krytycznymi głosami doktryny odnoszącymi się do zasadności wprowadzenia odpowiedzialności karnej za sprowadzenie bezpośredniego niebezpieczeństwa wyrządzenia znacznej szkody majątkowej spowodowanej nadużyciem udzielonych uprawnień lub niedopełnieniem ciążących obowiązków przez menedżera w obrocie gospodarczym. W odniesieniu do kryminalizacji bezszkodowej niegospodarności z art. 296 § 1a k.k. zgodzić się trzeba ze stanowiskiem, iż z polityczno-kryminalnego oraz kryminologicznego punktu widzenia jest ona całkowicie nieuzasadniona. Krytyczna ocena zarówno systemowa, jak i dogmatyczna odnosi się w zasadzie do całości przepisu art. 296 k.k., podnosząc głównie nieracjonalność ochrony szkodliwego nadużycia zaufania wyłącznie w sferze obrotu gospodarczego $^{40}$. Podkreślane niejednokrotnie w literaturze przedmiotu mankamenty owej regulacji, skutkujące trudnościami jej praktycznego zastosowania, sprawiają, że karnoprawna ochrona podmiotów korzystających z usług menedżerów ujęta w art. 296 § 1a k.k. jest iluzoryczna ${ }^{41}$. Można zatem w niedalekiej perspektywie spodziewać się całkowitego wyeliminowania art. 296 § 1a k.k. z obowiązującego porządku prawnego ${ }^{42}$. Należałoby się jednak zastanowić, czy zasadnie wskazywane mankamenty omawianej regulacji powinny przesądzić o całkowitej depenalizacji bezszkodowej niegospodarności, czy też raczej być podstawą do podjęcia prac nad

38 R. Zawłocki, [w:] Kodeks Karny. Część szczególna. Komentarz, red. R. Królikowski, R. Zawłocki..., s. 722.

39 M. Ligęza-Turlakiewicz, G. Turlakiewicz, op. cit., s. 63.

40 R. Zawłocki, [w:] Kodeks Karny. Część szczególna. Komentarz, red. R. Królikowski, R. Zawłocki..., s. 705.

41 M. Ligęza-Turlakiewicz, G. Turlakiewicz, op. cit., s. 72.

42 J. Giezek, [w:] Kodeks Karny. Część szczególna. Komentarz, red. J. Giezek..., s. 1172.

Nowa Kodyfikacja Prawa Karnego 46, 2017

(C) for this edition by CNS 
doprecyzowaniem art. 296 § 1a k.k. Karalność patologii gospodarczej w postaci zachowań polegających na nadużyciu uprawnień czy niedopełnieniu obowiązków przez menedżera, nawet w przypadku powstania skutku jedynie w postaci sprowadzenia bezpośredniego niebezpieczeństwa wyrządzenia znacznej szkody majątkowej, jest uzasadniona. Mimo że ryzyko gospodarcze jest nieodzownym czynnikiem wpływającym na podejmowanie decyzji, to jednak zachowania menedżera nie powinny wykraczać poza ustalone przepisem ustawy, decyzją właściwego organu lub umową ramy w sposób powodujący bezpośrednie niebezpieczeństwo sprowadzenia na mandanta znacznej szkody majątkowej.

\section{The danger of causing a significant material damage as a result of a non-damage mismanagement offence}

\section{Summary}

The essence of the criminal conduct described in Article $296 \S 1$ a of Polish Penal Code is defined as causing the immediate danger of material damage caused by the perpetrator who deals with the financial matters or the economic activity of an individual, a legal person or an organizational unit without legal personality represented under a legal obligation, the decision of the appropriate authority or the contract, abuses the authority vested in him or her or fails to fulfill his or her duties. This article has been devoted to the analysis of the consequences of the crime of non-damage mismanagement, along with an indispensable indication of its critical systemic and dogmatic appraisals. And while the defects of analyzed regulation are justified, they should not prejudge the total depenalization of the crime of non-damage mismanagement.

Keywords: material damage, abuse of trust, non-damage mismanagement, Article 296 § 1a of Polish Penal Code. 